\title{
ACADEMIC INSTITUTION AS A SYSTEM AND SYSTEMS' APPROACH TO THEM AND ATTRIBUTES OF THEIR EXCELLENCE
}

\author{
Arun $\operatorname{Kumar}^{* 1} \otimes$ iD \\ ${ }^{*_{1}}$ M Sc, MBA, Assistant Professor, Department of Human Resource Management Shree Balaji \\ University, Pune, India
}

DOI: https://doi.org/10.29121/granthaalayah.v9.i1.2021.3012

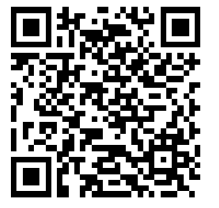

Article Type: Research Article

Article Citation: Arun Kumar. (2021). ACADEMIC INSTITUTION AS A SYSTEM AND SYSTEMS'

APPROACH TO THEM AND ATTRIBUTES OF THEIR

EXCELLENCE. International Journal of Research -GRANTHAALAYAH, 9(1), 271-278.

https://doi.org/10.29121/granthaa layah.v9.i1.2021.3012

Received Date: 05 January 2021

Accepted Date: 31 January 2021

Keywords:

Institution

Economic

Physical

Regulation

\section{ABSTRACT}

The System approach views the organization as a unified and purposeful system consisting of parts and subparts, which are interrelated. This helps a manager to understand it better. Activity in any part may affect all other parts of the organization. A system can be organisational, economic, biological, physical, social, governmental etc. The concept of systems approach was initiated in ancient Indian system of medicine. During World War II, this concept was applied to education technology. The body of people which constitutes an academic institution is influenced by the environment of society, other institutions, industry, government and politicians. Hence to consider a holistic approach an academic institution must be viewed as a system. Pupils entering the academic institutions are the input and results and their placements are the output of academic Institutions. Feedback and diagnosis of the result are activities influenced by the environmental elements. Attributes of an academic institutions from systems approach should be its Interdependence, Holism - emergent properties, Goal seeking, Open system, Transformation, Entropy, Regulation, Hierarchy, Equifinality, Multifinality.

\section{INTRODUCTION}

\subsection{MEANING OF THE TERM "SYSTEM"}

- For the purpose of understanding, "system" is dynamic and complex whole, wherein parts and subparts interact with each other, if there is any change brought into any of its part.

- A system is better understood as a community which is situated within an environment;

- System interacts with its environment, where may be energy, may be material and/ or may be information flows from and to its external surroundings.

- Systems often seek equilibrium however it can exhibit dynamism, sometimes may be chaotic, or exponential behavior.

- Group of items or objects forming a unified whole, therefore, could be called a system.

- We can also define system as "organized or established procedure", or a methodically arranged set of ideas, principles, methods or procedure" 
In nut shell, therefore, we can say that a system is "a collection of elements, interacting with each other to achieve a common goal". - Crunkilton and Finch (1999).

\section{INDIA; THE ORIGINATOR OF SYSTEMS APPROACH}

It could be the eye opener to many that in the western world systems approach developed much later than India. The very concept of Ayurveda is founded on the systems approach. Tritriangular Ayurvedic Model of Eco-Genetic Holism assumes human energy to be encased with in three triangles. Refer figure-1. Sun, water and air form the outer environmental triangle comprising the ecology. The inner triangle sustains living species or the biological setting which comprises of the flora and fauna. They are charecterised by the pitta, kafa and vata. The inner most triangle which supports the human energy is primarily charecterised by Teja, Oja and Prana. Ancient ayurvedic texts Charaka Samhita as early as 700 BC dealt in detail with the holistic system of medicine. Susruta Samhita (600 BC) on Surgery and Samhitas of Vagbhata 300 BC on therapeutics, Madhava Nidana (900 AD) on diagnostics, Sarangadhara(1300AD) on therapeutics and Bhava Prakasa(1600 AD) on Herbs \& Drugs maintained the systems approach to human health.

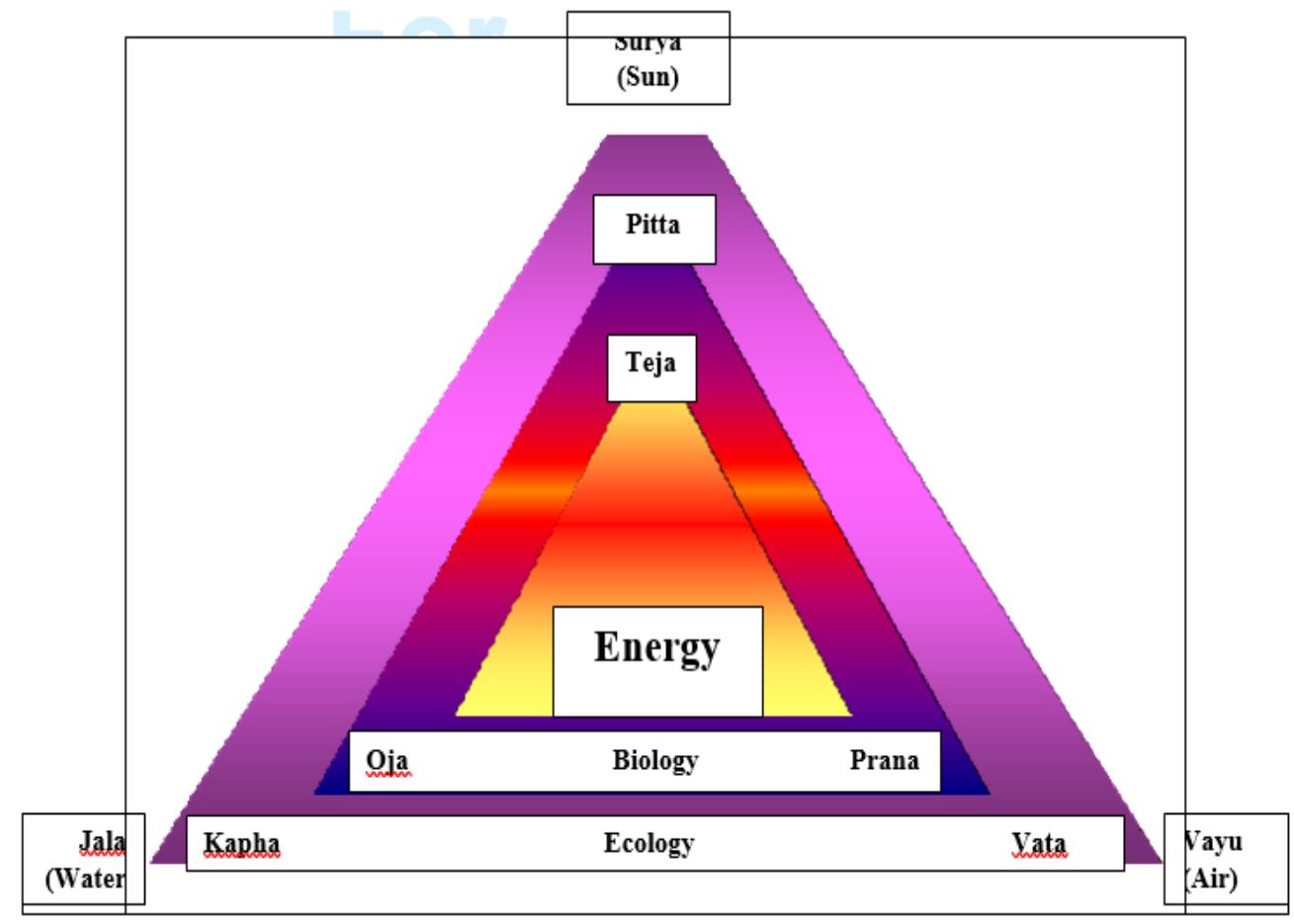

Figure 1: Tritriangular Ayurvedic Model of Eco-Genetic Holism

\section{COMPONENTS OF SYSTEMS APPROACH}

The systems approach has two basic components: elements and processes.

Elements: which are measurable and can be linked together. They may also be objects, events, patterns, or structures.

Processes: which changes elements from one form to another. They may also be activities, relations, or functions.

In a system, the elements or processes are grouped in order to reduce the complexity of the system for conceptual or applied purposes. Depending on the system's design, groups or the interfaces, it can be either elements or processes. Understanding the nature of this variation is central to the application of systems theory to problemsolving. 
According to biologist Von Bertalanffy, if one separates a living organism from its surroundings it will die shortly because of lack of oxygen, water and food. Hence organisms are open systems. Therefore, the characteristic of open systems is that they interact with other systems outside themselves. This interaction has two components: input, that what enters the system from the outside, and the output, that what leaves the system for the environment. The output of a system is in general a direct or indirect result from the input. The transformation of input into output by the system is usually called throughput.

\section{EVOLUTION OF EDUCATIONAL TECHNOLOGY SINCE THE WORLD WAR II}

Educational technology emerged as a recognized discipline during the 1940's and 1950's. This model embraced all possible means including hardware and software. The hardware side is concerned with the actual equipment such as overhead projectors, slide projectors, tape recorders, television equipment, computers, etc. The software side, on the other hand, is concerned with various things that are used in conjunction with this equipment - like overhead transparencies, slides, audiotapes, videotapes, computer programs, and so on.

The first phase in the evolution of educational technology was regarding its hardware, which worked on the development of effective instructional equipment. However, when hardware eventually became available, it was found that there was a shortage of suitable software to use with it. This triggered a subsequent 'software phase', in which helped the development of suitable learning materials, often based on dominant theories of learning and perception. Thus, even within this early development of educational technology, we can identify changes in the interpretation of the term 'technology'.

However, at this stage in the development of educational technology, people connected to academia became aware that there was much in education which could be improved by thinking more carefully about all aspects of the design of teaching/learning situations.

The principal role of educational technology thus, is to help improve the overall efficiency and effectiveness of the teaching/learning processes, which can help in bringing improvement in many ways:

1) increase/ improve the quality of learning, or mastery of the subject;

2) decreases the time taken for learners;

3) increase/ improve the efficiency of teachers;

4) reduces the costs, without affecting quality;

5) increases the independence of learners, and the flexibility of educational options.

Recommendation for improvements is, therefore, based on the study of a particular system as a whole, together with knowledge of appropriate educational research findings and theories and models of learning. In many cases, ideas and practices drawn from such diverse fields as psychology, sociology, business management and systems analysis are helpful in improving educational system giving better results.

In applying this technology for bringing improvements in education approach, changes are not made to a system for its own sake, but for good educational reasons that are generally based on research findings.

Educational technology is considered as technology of education and training. Within this concept, technology in education is seen mainly as one of the possible means for achieving this goal, with appropriate hardware and software developed to back up a specified strategy. Here it is important that the educational development or innovation is systematically and scientifically planned and executed. It is this 'System's approach' to educational technology is at the heart of the technology of education. The relationships between the various aspects of educational technology that have been discussed are shown in Figure 2. 


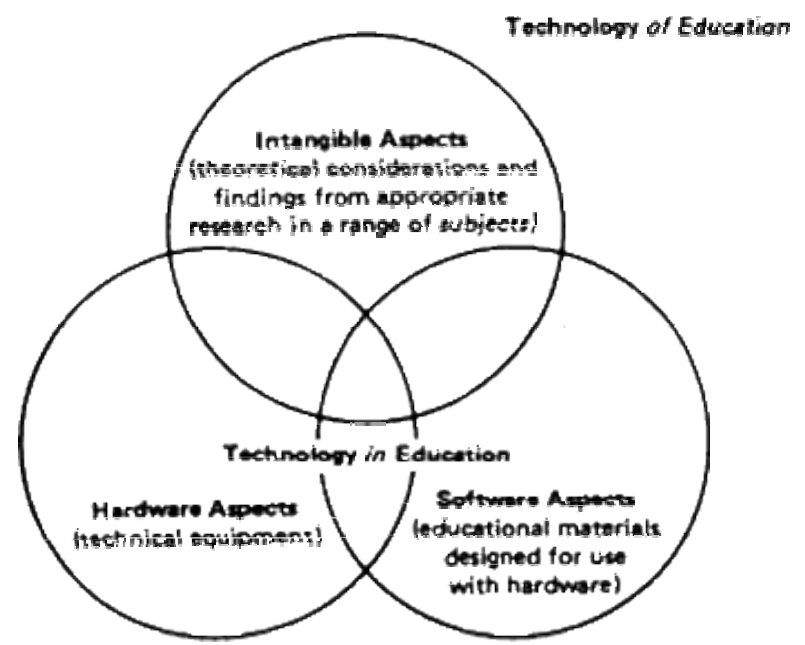

Figure 2: The relationships between the different aspects of educational technology

\section{THE SYSTEMS APPROACH IN EDUCATIONAL TECHNOLOGY}

The systems approach to the design and analysis of teaching/learning situations is the fundamental basis of the majority of modern educational technology developments. However, the terms system and systems approach may have variety of interpretations. Let us therefore take a look at these terms in order to define the way in which it is used by us.

In general, a system consists of interrelated parts and subparts that together constitute a larger whole. These component parts, or elements of the system are linked with one another, directly or indirectly, and any change in one or more of its elements may impact the overall performance of the system. A simple system is illustrated schematically in Figure 3.

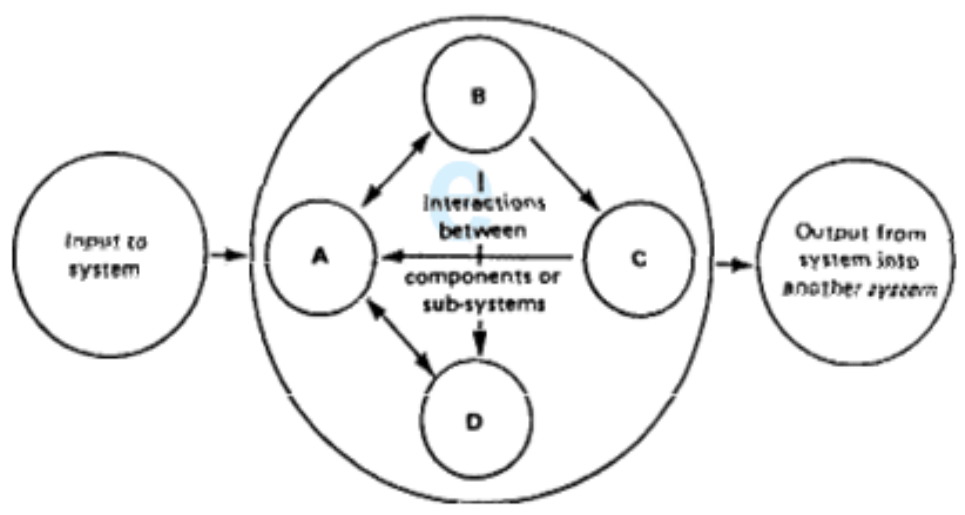

Figure 3: A typical system

Here in Figure 3, the system consists of four distinct elements A, B, C, D, which are related to and/ or dependent upon each other as indicated. Here some interrelationships may be two- way, while others may be just one-way. These elements may themselves be capable of further breakdown into other smaller components, and may thus be regarded as sub- systems of the overall system.

\section{ACADEMIC INSTITUTION}

The body of people which constitutes an academic institution is influenced by the environment as shown in the fig 6 which is consists of Families, the Society, Government, Politicians and other academic institutions and industry. The academic institution which has been represented as an entity in the form of a circle has to function under several environmental influences. It is an entity because it is a well-defined group and it has a definite purpose i.e. "To impart 
education and to enrich the world of knowledge". The entity has porous boundaries and the interaction with and the influence of, the external factors are continuous. These influences vary in degree or strength from time to time.

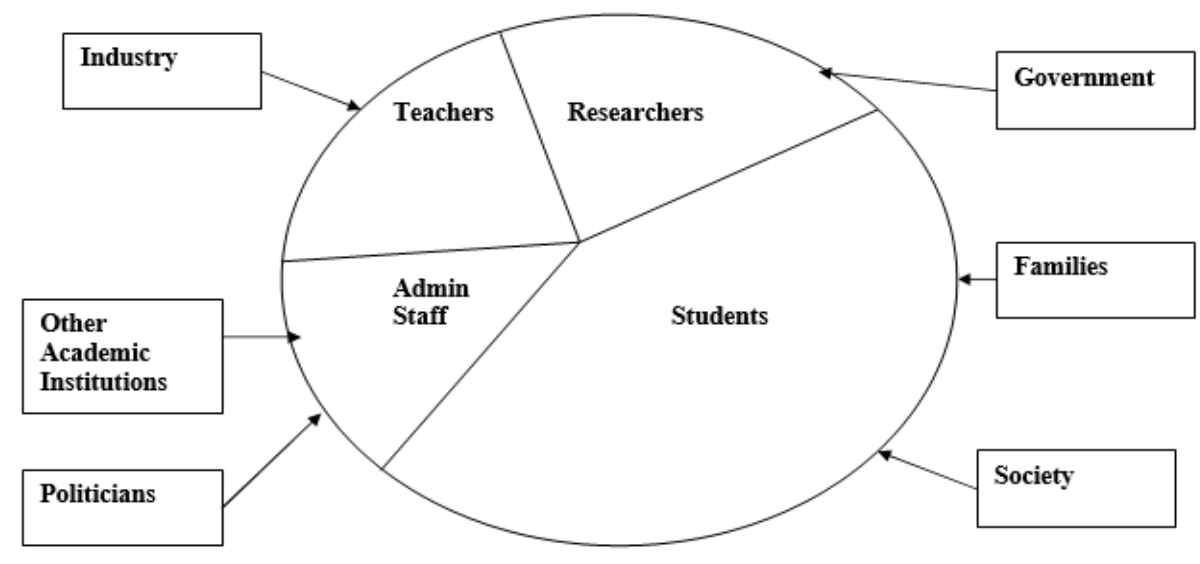

Figure 4: Academic Institution as a System

\section{SCHEMATIC MODEL OF SYSTEM APPROACH OF AN ACADEMIC INSTITUTION}

The schematic model through the system approach of academic institution has been presented in fig. 5 . Feedback and diagnosis are guided by the environmental elements shown in fig. 4.

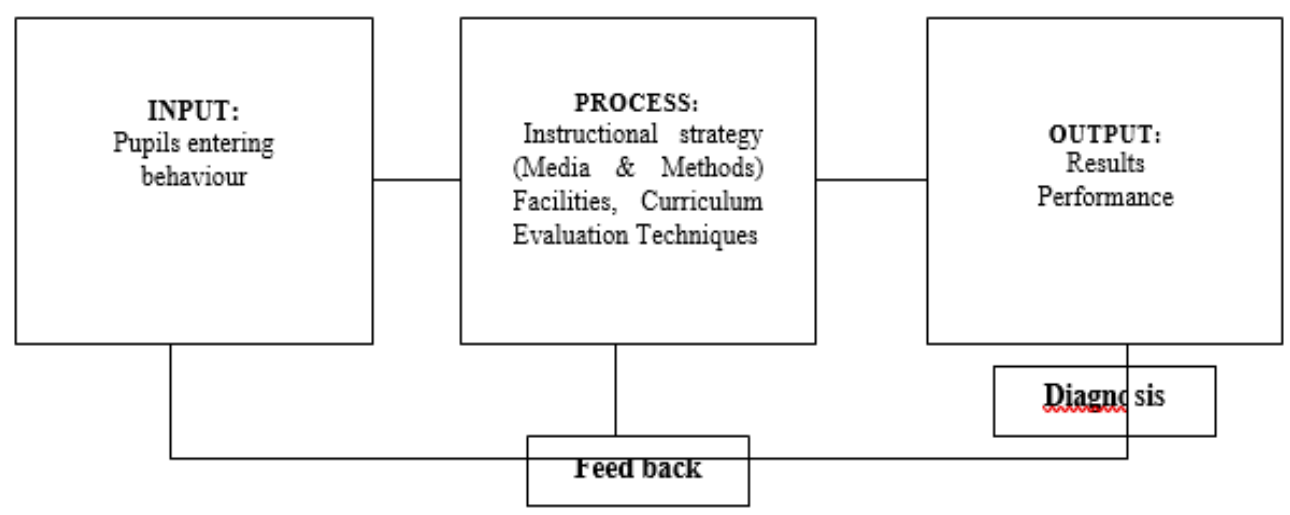

Figure 5: Input/ Output of academic Institution and Feedback and diagnosis through the environmental elements

\section{THE ATTRIBUTES OF EXCELLENCE THROUGH SYSTEMS APPROACH}

Any educational institution should incorporate following attributes for excellence: -

- Interdependence

- Holism - emergent properties

- Goal seeking -

- Open system

- Transformation

- Entropy

- Regulation

- Hierarchy

- Differentiation

- Equifinality

- Multifinality 
Interdependence: May it be academics, administration, management or extracurricular activities, an incessant interaction, not only with other academic institutions, but also with the statutory governmental bodies, industries, policy formulation level politicians and students' families in particular and society in general is highly solicited for the excellence of any academic institution. Hence while implementing any reform in the academic institution attention must be paid to the social economics, political and cultural subsystem of the environment.

Holism - emergent properties: Students' demand of syllabus, curriculum or the stream in view of the market needs or the teacher's aspirations, wages and evolution of teaching needs are guided by the environmental demands keeping in view of the holism in consideration. Futuristic planning, therefore, has to be based on advanced assessments of the emergent properties with holism in mind.

Goal seeking: For any academic institution a systemic interaction between subsystems like teaching faculty, administration or the students and its supersystem viz affiliating university, industries and society at large should result in some goal or final state of output setting.

Open system: Admitting additional inputs from the environment should be a continuous process for any academic institution. For example, visits of teachers to other institutions and guest faculty from other institutions, parents' teachers meet, regular visits to industries and vice versa are important activities for the wholesome growth of any institution.

Transformation: Instructional strategy, media \& methods of teaching, qualified facilities, Curriculum, evaluation techniques are some significant sub processes to achieve the goal of any academic institution.

Entropy: There must be a system to address to any disorder in any academic institution. It could be student's indiscipline, in class room or in campus or the hostels or it could be teachers or non-teaching staff's violation of laid down or desired norms, for smooth functioning of the internal processes.

Regulation: A method of feedback is necessary for academic institution to operate predictably well. These regulations must be flexible to meet the environmental demands.

Hierarchy: In an academic institution the complex wholes are made up of smaller subsystems e.g departments, laboratories, library, sport units, NCC units etc. Thus, a structured organizational functioning is essential. The chain of hierarchy, therefore, must be clearly defined. The delegation of authority in the command and control of subsystems is essential. Conversely upward flow of information from peon level to top management should also be made equally smooth process for any academic institution.

Differentiation: Specialized units perform specialized functions in any organization. In an academic institution, too, there is need to have such units e.g. Research Centre, Health clubs, Hobby clubs etc. with distinguishable and varied activities as subsystems but part of the supersystem. All these differentiable subsystems should continually interact within themselves and also with the apex management of the academic institution.

Equifinality: Alternative ways of attaining the same objectives through various processes is known as Equifinality. This is also known as convergence. All the subsystem processes, therefore, should device alternative approaches or methods to achieve their objectives. For example, class room teaching need not be only delivery of lectures. Teaching and learning goals could also be achieved by demonstrations, audio-visual aids, excursions, computer simulations or laboratory experiments. Interactions with modelling clubs, science clubs, dramatics or visits to industries could also become alternative methods to finally converge on the same objective of teaching and learning.

Multifinality: Attaining alternative objectives from the same inputs is very important attribute of any educational institution. This is also known as divergence. Thus, by using the tenet of "Multifinality", an educational institution could be considered to be:

- an "Education system" from the perspective of the society

- a "Placement system" from the perspective of students

- a "Personality development system" from the perspective of students and also their families.

- an "entertainment system" from the perspective of students and staff

- a "social system" from the perspective of local residents

- a " Research and collaborative system" from the perspective of faculty and students

- a "Employment system" from the perspective of all staff.

- a "profit making system" from the perspective of management and owners. 
Arun Kumar

\section{SOURCES OF FUNDING}

This research received no specific grant from any funding agency in the public, commercial, or not-for-profit sectors.

\section{CONFLICT OF INTEREST}

The author have declared that no competing interests exist.

\section{ACKNOWLEDGMENT}

None.

\section{REFERENCES}

[1] Russell L. Ackoff (1999) Ackoff's Best: His Classic Writings on Management. (Wiley) ISBN 0-471-31634-2

[2] Béla H. Bánáthy (1996) Designing Social Systems in a Changing World (Contemporary Systems Thinking). (Springer) ISBN 0-306-45251-0

[3] Béla H. Bánáthy (2000) Guided Evolution of Society: A Systems View (Contemporary Systems Thinking). (Springer) ISBN 0-306-46382-2

[4] Ludwig von Bertalanffy (1976 - revised) General System theory: Foundations, Development, Applications. (George Braziller) ISBN 0-807-60453-4

[5] Peter Checkland (1981) Systems Thinking, Systems Practice. (Wiley) ISBN 0- 471-27911-0

[6] Peter Checkland, Jim Scholes (1990) Soft Systems Methodology in Action. (Wiley) ISBN 0-471-92768-6

[7] Peter Checkland, Jim Sue Holwell (1998) Information, Systems and Information Systems. (Wiley) ISBN 0-47195820-4

[8] Peter Checkland, John Poulter (2006) Learning for Action. (Wiley) ISBN 0-470- 02554-9

[9] C. West Churchman (1984 - revised) The Systems Approach. (Delacorte Press) ISBN 0-440-38407-9.

[10] John Gall (2003) The Systems Bible: The Beginner's Guide to Systems Large and Small. (General Systemantics Pr/Liberty) ISBN 0-961-82517-0

[11] Jamshid Gharajedaghi (2005) Systems Thinking: Managing Chaos and Complexity - A Platform for Designing Business Architecture. (Butterworth- Heinemann) ISBN 0-750-67973-5

[12] Charles François (ed) (1997), International Encyclopedia of Systems and Cybernetics, München: K. G. Saur.

[13] Charles L. Hutchins (1996) Systemic Thinking: Solving Complex Problems CO: PDS ISBN 1-888017-51-1

[14] Bradford Keeney (2002 - revised) Aesthetics of Change. (Guilford Press) ISBN 1- 572-30830-3

[15] Peter M. Senge (1990) The Fifth Discipline - The Art \& Practice of The Learning Organization. (Currency Doubleday) ISBN 0-385-26095-4

[16] Lars Skyttner (2006) General Systems Theory: Problems, Perspective, Practice (World Scientific Publishing Company) ISBN 9-812-56467-5

[17] Frederic Vester (2007) The Art of interconnected Thinking. Ideas and Tools for tackling with Complexity (MCB) ISBN 3-939-31405-6

[18] Gerald M. Weinberg (2001 - revised) An Introduction to General Systems Thinking. (Dorset House) ISBN 0932-63349-8

[19] Brian Wilson (1990) Systems: Concepts, Methodologies and Applications, 2nd ed. (Wiley) ISBN 0-471-927163

[20] Brian Wilson (2001) Soft Systems Methodology: Conceptual Model Building and its Contribution. (Wiley) ISBN 0-471-89489-3

[21] O'Connor, J. \& McDermott, I. (1997). The Art of Systems Thinking: Essential Skills for Creativity and ProblemSolving. San Francisco: Thorsons Publishing. p. 11.

[22] Capra, F. (1996) The web of life: a new scientific understanding of living systems (1st Anchor Books ed). New York: Anchor Books. p. 30 
Academic Institution as A System and Systems' Approach to Them and Attributes of Their Excellence

[23] Skyttner, Lars (2006). General Systems Theory: Problems, Perspective, Practice. World Scientific Publishing Company. ISBN 9-812-56467-5. 